\title{
Diagnostic Analysis of the Teaching Style Inventory of Teacher-Education and Non-Teacher Education Faculty in an International Setting
}

\author{
Lina Sobrepena Calucag, Ph.D \\ Head, Math and Science Department, College of Engineering, AMA International University - Bahrain
}

\begin{abstract}
Teaching Style Inventory designed to examine teachers' affective learning goals for their students and teaching methods used to support their learning goals. It is a diagnostic tool for curriculum designers and professional development specialists. This paper is a qualitative and quantitative research study that aimed to investigate the teaching style inventory of teacher-education and non-teacher education faculty in terms of educational philosophy, instructional planning, teaching methods, teaching environment, evaluation techniques, managing interactions in the class, and instructional effectiveness. Results showed that the two groups of faculty differ significantly in their teaching style inventory as assessed and evaluated by academic department heads and faculty. It is recommended that further revitalization be made on the teaching beliefs and teaching styles of teacher-education and non-teacher education faculty suited to international students for instructional effectiveness.
\end{abstract}

Keywords: teaching style inventory, teacher-education, non-teacher education, instructional planning, teaching methods, teaching environment, evaluation techniques, teaching characteristics, educational philosophy.

\section{INTRODUCTION}

The teachers are indeed at the helm of the educational process for they are in the strategic position to bring about favorable changes in the students, that is, to mold them into the kind of individual that our society wishes them to be. With the aforementioned in the mind, it is essential to know the teaching styles of teachers in the classroom, which greatly affect the students' achievements. Teaching Style Inventory designed to examine teachers' affective learning goals for their students and teaching methods used to support their learning goals. The Teaching Styles Inventory can produce quantitative results that can discern between different types of teachers (as determined by their teaching styles). It is a diagnostic tool for curriculum designers and professional development specialists. The potential value of the Teaching Styles Inventory is its ability to: measure a wide variability in teaching styles; provide a graphical output and description showing how teachers' learning goals for their students and teaching methods differ; and use a norm sample of teaching style data to provide the basis for a discriminate analysis of teachers or groups of teachers.

If teaching styles for particular teachers tracked with their students' scores on standardized tests, it may be possible to quantify the teaching styles that are most effective in helping certain types of students learn. The inventory maybe used as a diagnostic to identify areas in which teachers need the most assistance in their professional development, (CORD, 2012).

Teaching style refers to the way teachers teach, which includes their distinctive mannerisms, complemented by their teaching behaviors and choice of instructional strategies. The manner and pattern of interactions with students clearly shows effectiveness in promoting learning and self-esteem, (Caneo, 2001). Teachers rarely realize how their beliefs about teaching and learning Influence all of their teaching decisions coupled with the evidence that teacher are the most important school related factor affects the achievement of students.(Rice, 2003). In the same way, that each of us has a unique learning style and teachers have individual teaching styles. Each style meets the needs of some students better than others do. Most teachers tend to be analytic by inclination, whereas most students are global. Good teachers are intuitively aware of individual differences between students, and between themselves and individual learners.

Thoughtful teachers appreciate the strengths and limitations of their own instructional preferences. The teachers' prevailing teaching beliefs and styles affects the way they present information and how they interact with students, (Grashas, 2000). Teaching beliefs and styles are frequent held unexamined. Assessment of teachers thinks about as part of their regular planning regimen, (Hen 2008). As a result, there are still gaps in the research that remain unexplored. And or the research fully addressed associated between teaching beliefs and teaching styles.

The AMAIUB faculty over the years have developed certain teaching styles that affected students' achievements. They identified teaching styles as effective and ineffective. The University caters to different fields of specialization with which each 
college develops future professionals through relevant in the class, and instructional effectiveness. The training and learning opportunities that shall give each researcher opted to use this research method considering graduate a comprehensive and realistic picture of an the objective to obtain first hand data from the immersion in the actual setting in each of the graduate's field respondents. The descriptive-evaluative design is then of profession. However, faculty of the different colleges in appropriate for this research since this method is used the university is composed of teachers who are Teacher for gathering prevailing conditions. The 134 Education graduates and Non-Teacher Education graduates. respondents were chosen using slovin's formula for Further, both types of faculty manifest the same elements of non-teacher education faculty while total enumeration instructional effectiveness. Both should learn the science of for teacher-education faculty and academic heads in all pedagogy, so in their own classrooms, they can personally colleges.

implement it artistically.

With this, there are few comments from the students that some of their teachers can handle well the behavior of their students while for other teachers, they find difficulty in handling such. How their teachers relate to them is also an issue for them. All these assumed to be about the differences in the professional preparation or pre-service training of both teacher types. These teaching styles to a certain extent affect the achievement of students considering that the utilization of appropriate teaching styles influence the students in all learning experiences. With this in mind, the research will venture to assess the teaching style inventory of the teachereducation and non-teacher education faculty of AMAIUB for international students its implications to instructional effectiveness.

This study aimed to evaluate the teaching style inventory of faculty members in the different colleges of AMAIUB who are teacher education graduates and non-teacher education graduates. Specifically, the study attempted to:

(a) Assess and evaluate the teaching style inventory of the teacher-education and non-teacher education faculty as assessed and evaluated by the department heads and teachereducation and non-teacher education faculty in terms of the following aspects: Instructional planning, Teaching methods, Teaching environment, Evaluation techniques, Teaching characteristics and Educational philosophy. (b) Determine the problems encountered by the academic department heads, and faculty along the following aspects: evaluating techniques, eliciting of ideas and managing interactions in class; (c) Find the difference between the teaching style inventory of the teacher-education and non-teacher education faculty as assessed and evaluated by the academic department heads. (d) Find the difference on the selfassessed teaching style inventory of the teacher-education and non-teacher education faculty; and (e) Find the difference between assessment and evaluation of academic heads and self-assessment of teacher-education and nonteacher education faculty on the teaching style inventory.

\section{METHODOLOGY}

\section{Research Design}

This is a qualitative and quantitative research study, which aim to investigate the teaching inventory style of AMAIUB faculty. Moreover, the descriptive-evaluative research design was used to evaluate the teaching style inventory of faculty who are teacher education graduates and non-teacher education graduates in terms of educational philosophy, instructional planning, teaching methods, teaching environment, evaluation techniques, managing interactions

\section{Research Instrument}

The researcher adopted the Teaching Styles Inventory checklist (Dunn and Dunn, 2003). Two sets of questionnaires for academic department heads and faculty were used which consisted of two parts: The first part is the perceived evaluation on the teaching styles of teacher-education and non-teacher education faculty of AMAIUB in terms of instructional planning, teaching methods, teaching environment, evaluating techniques, and educational philosophy. The second part is the problems encountered along evaluating techniques, eliciting of ideas, and managing interactions in class. Face-to-face interviews were also conducted to supplement the data gathered by the questionnaire. These interviews were aimed at bridging the gap not answered by the quantitative data and clarified some missing links from the survey.

\section{Statistical Treatment of Data}

The researcher used the following statistical treatments/methods in order to validate the data gathered: Mean was used to determine the assessment and evaluation of the academic heads and faculty on the teaching styles of the Teacher-Education and NonTeacher Education Professors in terms of the following aspects: Educational philosophy, Instructional planning, Teaching methods, Teaching environment, and Evaluation techniques. The t-test for uncorrelated mean was used to determine the difference between the (academic heads and faculty) assessment mean scores of the teacher-education and non-teacher education faculty.

\section{RESULTS AND DISCUSSION}

Figure below presents the teaching style inventory of the teacher-education and non-teacher education faculty as assessed and evaluated by the department heads. As to the instructional planning, results showed that most frequently used styles in terms of the preparation of instructional materials were the whole-class lessons, small- grouped assignments and the peer tutoring with their mean scores of 3.33 and 2.85 for teacher-education and non-teacher education faculty, respectively. On the other hand, task cards or games and the objectives varied for individuals were the rarely used styles. The result indicates that both the two groups of respondents have something in common in the utilization of styles in terms of instructional planning. However, education faculty used more styles frequently than occasionally as assessed and evaluated by the academic heads. 
Teaching style inventory of the teacher-education and non-teacher education faculty as assessed and evaluated by the academic heads

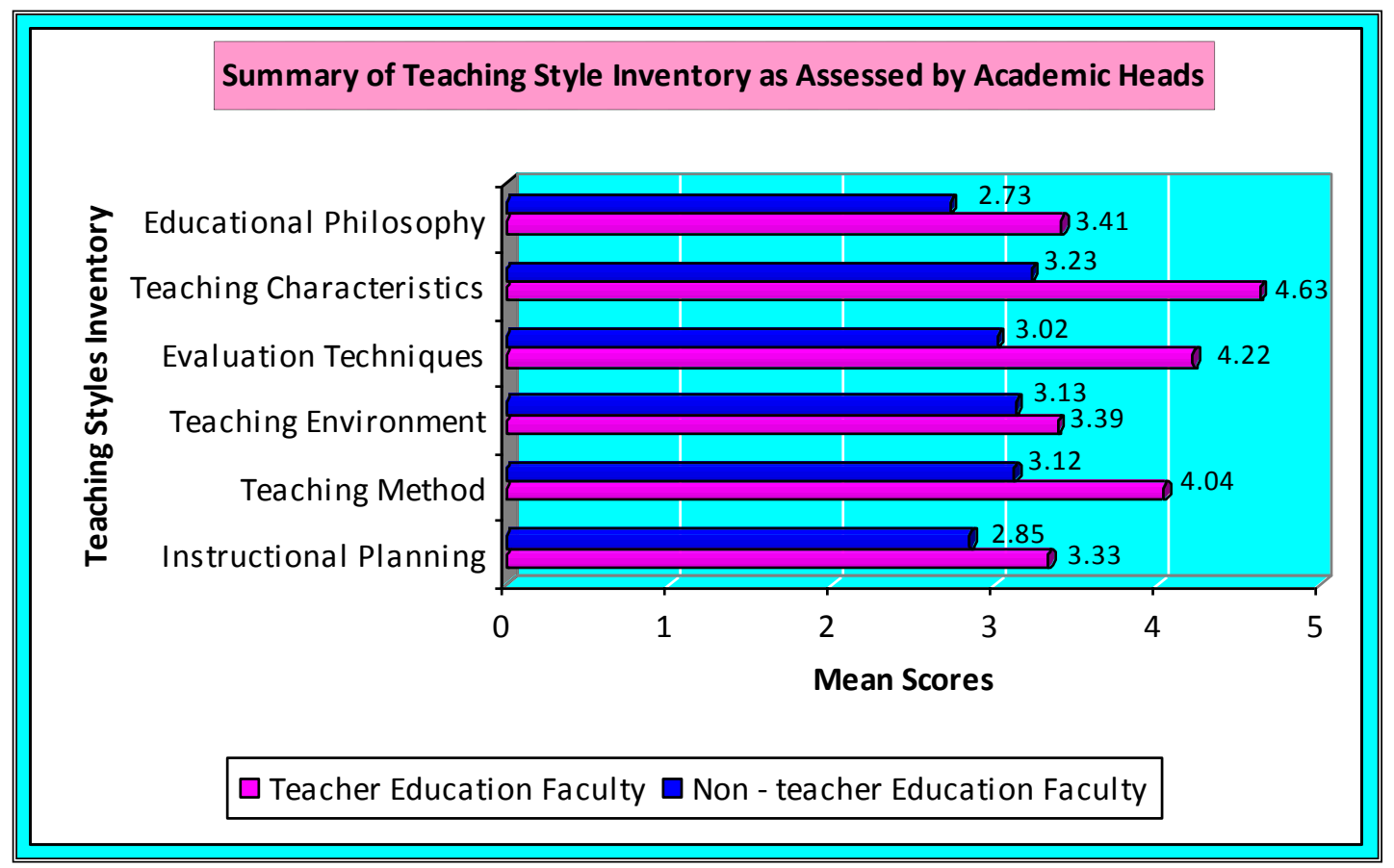

Fig. 1 Summary of Teaching Style Inventory as Assessed and evaluated by Academic Heads

The teacher education faculty with a mean score of 4.04 This implies that the teacher education faculty could always used lecture, class discussion, teacher demonstration, have conducted effective teaching styles for better and the small group methods while the faculty of other learning outcomes from the students. Furthermore, on disciplines, all the teaching methods used occasionally with educational philosophy, it was that the education faculty a mean score of 3.12. On teaching environment, teacher had frequently used most of the educational philosophies education faculty believed that effective learning achieved given. For the faculty of other disciplines, they had by grouping the students. While, one-to-one interaction of occasionally used most of the educational viewpoints the students with the teacher could be the effective way of presented. The overall mean scores 3.41 and 2.73 shows bringing about learning for the faculty of other disciplines. that the two groups of faculty respondents had generally The above table shows that the education faculty "to a used occasionally the educational philosophies in their greater extent" frequently used most of the room designs. teaching styles.

On the other hand, the faculty of other disciplines occasionally used all the designs though not to the same and equal extent. It is important that students are exposed and get accustomed to computers, teaching program, audios, videos and multimedia as possible tools in their studies, (Ritgero, 2010).

On evaluation techniques, the constructed exam evaluation practice was the only used technique by the faculty of other disciplines and the rest used occasionally with a mean score of 3.02. On the other hand, the following practices (Individual score compared to student objectives, Group scores compared to small-group objectives, Standardized achievement exams, Individual score compared to student's potential) were the most effective technique for the teacher education faculty to evaluate the students' performance with a mean score of 4.22. Moreover, on teaching characteristics, the figure above clearly shows that the education faculty demonstrated all characteristics suitable to the effective learning of the students. This is seen in the given mean scores 4.63 described as always. On the other hand, the nonteacher education faculty that could be effective in their teaching styles demonstrated some characteristics.

Figure below presents the summary of self-assessed teaching style inventory of teacher education and nonteacher education faculty. As to the instructional planning, the education faculty had occasionally assessed themselves as shown by the overall mean score of 3.45 while the faculty of other disciplines had assessed themselves frequently as shown by the overall of 3.51. The result indicates that they had assessed to have use frequently in the preparation of instructional materials in their teaching styles. On teaching method, there is a clear presentation that both the two groups of faculty respondents had assessed frequently and occasionally the same teaching schemes. This simply means that both had exhibited the same teaching schemes in their teaching styles. Teaching methods are planned interactions between teacher and learners that result in the accomplishment of a specific outcome, (Metzler and Rink, 2002).

On teaching environment, the two types of faculty had different perceptions on what grouping used frequently and occasionally to achieve a better learning outcome from the students. 
Self-assessed teaching style inventory of the teacher-education and non-teacher education faculty

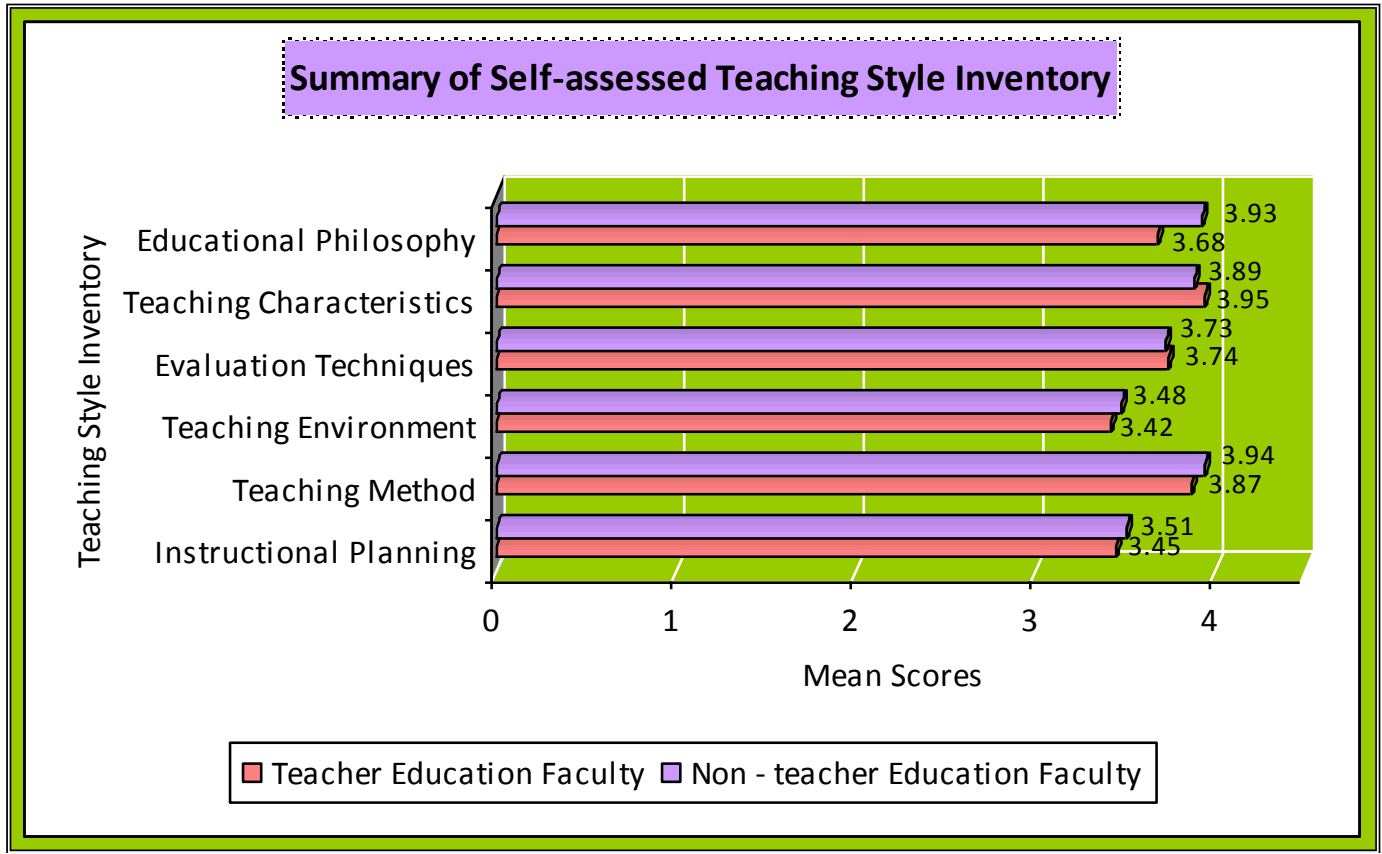

Fig. 2 Summary of Self- Assessed Teaching Style Inventory

The results showed that the education faculty had assessed frequently and occasionally use some room designs. On the other hand, the faculty of other disciplines had assessed to use all the room designs occasionally. Education faculty could have perceived that instructional setting is one factor that could induce learning among the
students. Good model of teaching is a description of a good learning environment, (Joyce, 1996).

On evaluation techniques, teacher education faculty had used all the evaluation practices frequently except for the first evaluation practice that used always. In similar sense, the faculty of other disciplines had also used frequently all the evaluation practices. Both had also almost the same overall mean scores of 3.74 and 3.73 that described as frequently. These results would only indicate that both the types of faculty had established in themselves the relevance of all the evaluation practices in their teaching styles to facilitate better learning among the students. Moreover, on teaching characteristics, teacher education faculty had displayed similar self-assessment on the teaching characteristics of the faculty. It is also observable that both types of faculty had considered teaching characteristics (students' learning styles, challenging and Lesson plan-oriented) as the first prioritized characteristics demonstrated by both of them in their teaching styles while facilitating lectures and learning on the students. The result only implies that any teaching characteristic agreeable and possible in the teaching style to facilitate learning, the faculty would show similar and the same perception. On educational philosophy, teacher education faculty used the educational philosophies frequently and occasionally. On the other hand, the faculty of other disciplines had assessed themselves to have only the educational viewpoint-the multiage groupings, used occasionally while the rest used frequently. The mean scores of self-assessment of the faculty of other disciplines on the educational viewpoint were higher than that of the education faculty. The result implies that the education faculty was somehow selective in the choice of philosophy applied and used in the classroom discussion.

Problems Encountered in the Teaching process along Evaluation Techniques

Evaluation rooted in "value" and derived from the Latin valeo, (to be strong), indicates a judgment of how well the student strengths correspond with the "values" of the concerned communities, including the department, school and the profession, (Pangaro,2005; Oxford English Dictionary, 1971). Inappropriate evaluation techniques could be the wrong vehicles towards learning outcomes' evaluation. Cook (2012), cited that learning evaluations help teachers understand which skills students have mastered and which ones have left to learn, thus, it will assist the teacher in planning further instruction for students. AMAIUB faculty encountered numerous problems in the evaluation techniques used in the teaching-learning process. One way to monitor the consistency of the problems encountered, the researcher asked the perceptions of the academic department heads and faculty on evaluating techniques. Consider the following statements from faculty's perceptions both nonteacher education and teacher-education faculty:

"Due to the extreme nature of students, evaluation techniques vary from easy to average thus major examinations tend to be difficult for the students"

"Student differences and language barriers are the main reasons why the teacher needs to shift from one evaluation technique to another"

"Different group of students for different evaluation techniques" 
From the faculty's perspective, these particular evaluation techniques may be well suited to the content taught or their personal style, but the following statements from the academic department heads show that they perceived this ways of teaching of the faculty somewhat differently:

"Teachers don't vary evaluation techniques throughout the term"

"Insufficient time for different evaluating techniques due to many activities not planned"

"Difficulty with time resource"

In cases like this one, it is not a matter of identifying whose perceptions are more accurate, but rather, finding ways that the faculty's, students' and department heads' expectations and evaluations can be aligned so that students are able to learn and assess what the instructor intends them to. Incorporating a variety of evaluation techniques into instructional plan will ensure that all students have a chance to demonstrate what they have learned in a familiar format.

\section{Problems Encountered in the Teaching Process along Eliciting of Ideas}

Eliciting of ideas is a technique used by the teacher during the lesson that involves the language learner in the process of discovering and understanding language, (ESL Focus Teacher expert, 2012). Questioning is a bridge to draw out ideas from students. It is an essential component of effective teaching, utilizing techniques dating back to the time of Socrates. Harris (2012), allude to the idea that questioning serves many purposes, not only deepening student understanding of the subject matter but also nurturing logical thought processes and encouraging imagination and creativity. This idea sold to the following opinions of the teacher-education professors, noted: "Teacher is only a facilitator and the discussion flow among students, so as to generate more ideas and students learn from each other"

"Opinions are welcome to elicit ideas from students"

"Teachers need to specify in details what the different terms mean before arriving at a very conclusive and effective idea"

AMAIUB teacher-education and non-teacher education faculty have a long way to achieve maximum participation of the students - for they are brazen out with the following observations:

"Students could hardly analyze due to lack of comprehension, lack of vocabulary, and lack of selfconfidence"

"Unfamiliar words make students to react.....eventually they do not understand the lesson neither can follow direction"

"Lack of competence in the English language use will hinder students to share their ideas during class discussions"

"Students are seem to be reluctant to show their ideas, scared of being wrong or not knowing"

These problems can be avoided if the teacher creates an accepting environment in which students feel comfortable expressing their thoughts. Harris (2012), concurred the statement that, answering a question poses the potential risk of embarrassment for students, ensure that the instructor or peers do not put down students. From the educator's standpoint, eliciting of ideas can serve to assess student understanding, reveal misconceptions and diagnose strengths and weaknesses.

Problems Encountered in the Teaching process along Managing Interactions in Class

Teaching is not a linear, one-way delivery of knowledge, but an interactive process that requires adapting to shifting contexts, demands of content, and student input, (CIDR, 2008). Managing interactions in class is about managing students having an active discussion during class. Interactions occur both between students with no lecturer present, and with the lecturer who probes student thinking among the whole group, (www.ryerson.ca, 2012). Many college instructors use lecture as the primary method of imparting information to students during class. Some, however, use group discussion to involve students in the topic. Stone (2012) pointed that, proponents of group interaction in learning propose that discussions help students see different perspectives on a topic and discussions also help develop habits of collaborative learning. Many teachers are facing dilemma in managing interactions in class, AMAIUB teacher-education and nonteacher education faculty are not exempted on this scenario. It is evident from the statement of a female teacher-education faculty, "Managing interactions in class can be challenging as our students are very "collective", vocal and outspoken when they choose to be. Often they do not listen to each other. They are either very enthusiastic and committed or disengaged. So most of the time, the two extremes exist in the classroom so it is tempting to focus on/with the enthusiastic students but the disengaged need even more attention. I always feel that many students do not believe in their own learning ability."

The statement corroborates with the idea of a science teacher-education professor, that, "academicallychallenged students lack confidence in interacting with their classmates, some students don't interact with the teacher nor with peers."

Stone (2012) quoted that, an effective instructor plans for group discussion. Decide whether the discussion will be with the whole class or broken into smaller groups. The idea was supported by an opinion of a teacher-education professor, that, "Every student is given the chance to express his/her views about a topic. At times, the teacher starts giving questions to students, then the students discussed among themselves, but most of the situations were taken for granted - the show must go on."

Apparently the statements was sided by academic department head and non-teacher education professor, respectively, and it quotes,

"Most students didn't seem to know when the proper time for raising inquiries of almost any circumstance; and late students disturbed ongoing class interactions."

It is necessary to revitalize teaching, to help the learner acquire knowledge and skills in an interactive 
environment. Effective instructors manage and utilize group discussion and interaction work in the classroom.

Table1. Difference between the Teaching Style Inventory of the Teacher-Education and Non-teacher Education Faculty as Assessed by the Academic Department Heads

\begin{tabular}{|l|l|l|l|}
\hline \multicolumn{1}{|c|}{ Teaching Styles } & $\begin{array}{l}\text { t-test for } \\
\text { Equality } \\
\text { of Means }\end{array}$ & $\begin{array}{l}\text { Sig. (2- } \\
\text { tailed) }\end{array}$ & Decision \\
\hline Instructional Planning & 2.991 & $\mathbf{. 0 1 2 *}$ & Reject Ho \\
\hline Teaching Methods & 2.879 & $\mathbf{. 0 3 5}$ & Reject Ho \\
\hline Teaching Environment & 1.287 & .215 & Accept Ho \\
\hline Evaluation Techniques & 9.164 & $\mathbf{. 0 0 0 *}$ & Reject Ho \\
\hline Teaching Characteristics & 13.73 & $\mathbf{. 0 0 0 *}$ & Reject Ho \\
\hline Educational Philosophy & 2.879 & $\mathbf{. 0 1 3} *$ & Reject Ho \\
\hline *Difference is significant at the 0.05 level (2-tailed)
\end{tabular}

Table 1 presents the difference between the teaching style inventory of the teacher-education and non-teacher education faculty as assessed and evaluated by the academic department heads. When the teacher-education and non-teacher education faculty were compared on their teaching inventory styles, results of the t-test showed that significant difference were observed on instructional planning $(p$-value $=.012)$, teaching methods $(p$-value $=$ $.035)$, evaluation techniques $(p$-value $=.000)$, teaching characteristics (p-value $=.012)$, and educational philosophy (p-value $=\mathbf{. 0 1 3})$. This is proven by the yielded p-values of said provisions which are noted to be lesser than .05. This means that teacher-education and non-teacher education faculty differs in their teaching inventory as assessed and evaluated by the academic department heads. The differences of the aforementioned teaching styles inventory manifested in figure 1. Moreover, when the teacher-education and non-teacher education faculty were compared on their teaching style inventory along teaching environment, computed t-value ( $p$-value $=.215)$ yield no significant difference $(p>.05)$. This indicates that whether faculty graduated teachereducation or non-teacher education program, their teaching inventory style on teaching environment are on the same level as assessed and evaluated by the academic department heads.

Table 2 presents the difference between the selfassessment of the teacher-education and non-teacher education faculty on the teaching style inventory. When the teacher-education and non-teacher education faculty were compared on their teaching inventory styles, results of the t-test show that no significant difference is observed on instructional planning $(p-v a l u e=.445)$, teaching methods (p-value $=.555)$, teaching environment $(p$ value $=.310)$, evaluation techniques $(p$-value $=.978)$, and teaching characteristics $(\mathbf{p}$-value $=.070)$ yielded $\mathrm{p}$ values of said provisions that are noted to be greater than .05. This means that teacher-education and non-teacher education faculty do not differ in their teaching inventory, their teaching inventory on teaching environment are on the same level as perceived by them.
Table2. Difference on the Self- Assessed Teaching Style Inventory of the Teacher-Education and Non-teacher Education Faculty

\begin{tabular}{|l|l|l|l|}
\hline Teaching Styles & $\begin{array}{l}\text { t-test for } \\
\text { Equality } \\
\text { of Means }\end{array}$ & $\begin{array}{l}\text { tailed) } \\
\text { taision }\end{array}$ & \\
\hline Instructional Planning & -.792 & .445 & Accept Ho \\
\hline Teaching Methods & -.632 & .555 & Accept Ho \\
\hline Teaching Environment & -1.044 & .310 & Accept Ho \\
\hline Evaluation Techniques & .029 & .978 & Accept Ho \\
\hline Teaching Characteristics & 2.137 & .070 & Accept Ho \\
\hline Educational Philosophy & -3.400 & $.005 *$ & Reject Ho \\
\hline *Difference is significant at the 0.05 level (2-tailed) \\
\hline
\end{tabular}

Moreover, when the teacher-education and non-teacher education faculty were compared on their teaching inventory style along educational philosophy, computed t-value (p-value $=\mathbf{. 0 0 5}$ ) yield significant difference $(p<.05)$. The result implies that the teacher - education faculty were somehow selective in the choice of philosophy applied and used in the classroom discussion. This means that teacher-education and non-teacher education faculty differs in their self-assessed teaching style inventory.

Table 3a presents the difference between the perceived assessment of academic department heads and selfassessment of the teacher - education faculty on the teaching style inventory. When the teacher-education and non-teacher education faculty were compared on their teaching inventory styles, results of the t-test show that significant difference were observed on evaluation techniques $(p$-value $=\mathbf{. 0 0 7})$ and teaching characteristics (p-value $=\mathbf{. 0 0 0})$. This is proven by the yielded p-values of said provisions which are noted to be lesser than .05. This means that teacher-education and non-teacher education faculty differs in their teaching style inventory as assessed and evaluated by academic department heads and selfassessment of faculty.

Table 3a Difference between the assessment of Academic Department Heads and self-assessment of the Teacher-Education Faculty on the Teaching Style Inventory

\begin{tabular}{|l|l|l|l|}
\hline Teaching Styles & $\begin{array}{l}\text { t-test for Sig. (2-Decision } \\
\text { Equality } \\
\text { of Means }\end{array}$ & tailed) & \\
\hline Instructional Planning & .595 & .564 & Accept Ho \\
\hline Teaching Methods & .723 & .502 & Accept Ho \\
\hline Teaching Environment & .410 & .687 & Accept Ho \\
\hline Evaluation Techniques & 3.808 & $\mathbf{. 0 0 7} *$ & Reject Ho \\
\hline $\begin{array}{l}\text { Teaching } \\
\text { Characteristics }\end{array}$ & 8.737 & $\mathbf{. 0 0 0} *$ & Reject Ho \\
\hline Educational Philosophy & 1.211 & .247 & Accept Ho \\
\hline
\end{tabular}

*Difference is significant at the 0.05 level (2-tailed)

Moreover, when the teacher-education and non-teacher education faculty were compared on their teaching style inventory along instructional planning $(p$-value $=\mathbf{. 5 6 4})$, 
teaching methods (p-value $=\mathbf{. 5 0 2})$, teaching The education faculty believed that effective learning environment (p-value $=\mathbf{. 6 8 7})$, and educational could be best achieved by grouping the students. While, planning $(\mathbf{p}$-value $=\mathbf{2 4 7})$, computed t-values yield no one-to-one interaction of the students with the teacher significant differences ( $\mathrm{p}>$.05). This indicates that whether could be the effective way of bringing about learning for faculty graduated teacher-education or non-teacher the faculty of other disciplines.

education program, their teaching inventory on teaching environment are on the same level as assessed and evaluated by the academic department heads and selfassessment of faculty.

Table 3b Difference between the assessment of Academic Department Heads and self-assessment of the Non-teacher Education Faculty on the Teaching Style Inventory

\begin{tabular}{|l|l|l|l|}
\hline Teaching Styles & $\begin{array}{l}\text { t-test for } \\
\text { Equality } \\
\text { of Means }\end{array}$ & & \\
tailed) & & \\
\hline Instructional Planning & 4.664 &. $\mathbf{0 0 1} *$ & Reject Ho \\
\hline Teaching Methods & 4.487 &. $\mathbf{0 0 6}^{*}$ & Reject Ho \\
\hline Teaching Environment & 4.445 & $\mathbf{. 0 0 0}^{*}$ & Reject Ho \\
\hline Evaluation Techniques & 9.571 & $\mathbf{. 0 0 0}^{*}$ & Reject Ho \\
\hline Teaching Characteristics & 5.240 & $\mathbf{. 0 0 1} *$ & Reject Ho \\
\hline Educational Philosophy & -1.427 & $\mathbf{. 0 0 0} *$ & Reject Ho \\
\hline
\end{tabular}

*Difference is significant at the 0.05 level (2-tailed)

Table $3 b$ presents the difference between the perceived assessment of academic department heads and selfassessment of the non-teacher education faculty on the teaching style inventory. When the teacher-education and non-teacher education faculty were compared on their teaching inventory styles, results of the t-test show that significant difference were observed on instructional planning $(p$-value $=\mathbf{. 0 0 1})$, teaching methods $(p$-value $=$ .006), teaching environment (p-value $=.000$ ), evaluation techniques (p-value $=.000)$, teaching characteristics $(p$-value $=.001)$, and educational philosophy (p-value $=\mathbf{. 0 0 0})$. This is proven by the yielded $p$-values of said provisions which are noted to be lesser than .05. This means that teacher-education and non-teacher education faculty differs in their teaching style inventory as assessed and evaluated by academic department heads and self-assessment of instructors.

\section{CONCLUSIONS}

Though there are similarities, the education faculty had shown to use more styles frequently in the preparation of instructional materials as assessed and evaluated by the department heads. Yet as per self-assessment, the other disciplines had used instructional planning frequently than occasionally.

The faculty assessed themselves to have used most of the teaching schemes frequently while the department heads declared the teacher education faculty to have used most of the given schemes "to a great extent". The two types of faculty had different perceptions on what grouping for teaching setting is to be used frequently and occasionally to achieve a better learning outcome from the students.

Most of the room designs were frequently used by the education faculty and occasionally by the faculty of other discipline. Room designs are effective for better learning. Instructional settings frequently used by the education faculty and occasionally by other disciplines.

The education faculty had always demonstrated all the teaching characteristics in their learning styles for better learning outcomes. Both the education faculty and the other disciplines had some educational philosophies/ viewpoints rarely used in their teaching styles. The Faculty and the department heads had different perceptions on the use of particular evaluation techniques used by the teachers as revealed by the faculty's responses.

The faculty has a long way to achieve maximum participation from the student specially drawing ideas from given questions or eliciting ideas and managing interactions during class discussions. The faculty differs in the teaching inventory styles as assessed by both the department heads and the faculty themselves.

\section{REFERENCES}

[1] Abdullah, Muhammad Kamarul Kabilan (Modified 2012). English Language Teachers' Profile and Their Teaching Styles. Masters thesis, Universiti Putra Malaysia.

[2] Behar-Horenstein et al (2006). "Teaching Style Beliefs among US and Israeli Faculty". Journal of Dental Education, University of Florida, Department of Educational Administration and Policy, P.O. Box 117046, Gainesville, FL 32611-7046; 352-392-2391, ext. 299 phone; 352-392-0038 fax; Lsbhoren@ufl.edu.

[3] Burgess, G. (2003). What makes a teacher; philosophy, learning style, or teaching style?. In D. Lassner \& C. McNaught (Eds.), Proceedings of World Conference on Educational Multimedia, Hypermedia and Telecommunications 2003 (pp. 2293-2295). Chesapeake, VA: AACE. Retrieved from http://www.editlib.org/p/11165.

[4] Burgio, Meredith (2012), "Teaching Characteristics that are Important for Effective Teaching", leHow.com, http://www.ehow.com/info_7864147_teaching-characteristicsimportant-teaching.html

[5] Caneo, V. (2001), "Association between Teaching Styles and Selected Variables: An Exploration of Outstanding Teachers in Higher Education Institutions, Manila, Philippines. cidr@u.washington.edu

[6] Clotfelter, Charles et al (2006). "Teacher-Student Matching and the Assessment of Teacher Effectiveness". NBER Working Paper 11936, National Bureau of Economic Research, Inc.

[7] Cook, Jessica. (2012). "Evaluation Methods \& Techniques,"eHow.com,

http://www.ehow.com/way_5306159_evaluation-methodstechniques.html

[8] Ebeling, G. (2000). "Adapting Your Teaching to Any Learning Style”, Phi Delta Kappa, Vol.82, No.3 247-248.

[9] Felder, R.M. (2002), "How Students Learn: Adapting Teaching Styles to Learning Styles", Frontier in Education Conference, North Carolina State University.

[10] Good et al (1997). "Looking in Classrooms", $7^{\text {th }}$ edition, Longman of Addison Wesley, Longman,Inc. New York, P359.

[11] Grasha, A. (1996). "Teaching with Style". Pittsburgh, PA: Alliance Publishers.

[12] Hanushek, Eric et al (2005), "Teacher, Schools and Academic Achievement" Econometrics, 73(2):417-418. 
[13] Harris, Amy. (2012). "How to Use Questioning as a Teaching Tool in the Classroom", | eHow.com.

[14] Heimlich, Joe et al, (2002), "Teaching Style: Where are we now?", Wiley Periodicals, Incorporated.

[15] Joyce et al, (1996). "Models of Teaching" $5^{\text {th }}$ edition, Simon \& Schuster, Co. P.11.

[16] Kay Mohanna et al (2007). "Developing your teaching style: Increasing effectiveness in healthcare teaching". Postgraduate Medical Journal, Staffordshire University.

[17] Mckaskey, Stephen, (2009). "Teaching and Learning Strategies of Illinois Secondary Career and Technical Education teachers". Southern Illinois University Carbondale.

[18] Metzler, M.W. (2000), "Instructional Model for Physical Education", Boston, DC: Allyn \& Ban.

[19] Meyer et al (2006). "The Approaches to Teaching Inventory: A Critique of Its Development and Applicability". British Journal of Educational Psychology, v76 n3 p633-649.

[20] Morgan, Kevin (2005). "Effects of Different Teaching Styles on the Teacher Behaviours that influence Motivational Climate and Pupil's Motivation in Physical Education', European Physical Education Review, Vol 11 No.3, 257-285, University of Wales Institute Cardiff, United Kingdom.

[21] Norbert, M. et al (2009). "Active versus Passive Teaching Styles: An Empirical Study of Student Learning Outcomes". Small Business Institute National Proceedings, Vol.33 No.1.

[22] Oxford English Dictionary, 1971.

[23] Pajak, Edward (2003), "Honoring Diverse Teaching Styles: A Guide for Supervisors", Association for Supervision and Curriculum Development. 1703 North Beaugard Street, Alexandria. http://www.ascd.org.

[24] Pangaro, Louis. (2005). "A Primer of Evaluation: Definitions and Important Distinctions in Evaluation. Alliance for Clinical Education, Nebraska medical Center.

[25] Rink, J.E. (2002), “ Teaching Physical Education for Learning (4 ${ }^{\text {th }}$ edition), Boston, DC: McGraw Hill.

[26] RITA DUNN and KENNETH DUNN (2003) "Teaching Style: Expanding Your Strengths-Your Way!'

[27] Ritgero et al (2010). “ Education, Experience and Endurance: A study of Teaching Methods in Secondary Schools, Haokoli Islands.

[28] Sheahan, Kyra, (2012). "About Different Teaching Methods in a Classroom"
|eHow.com, http://www.ehow.com/info_7923568_different-teaching-methodsclassroom.html

[29] Stone, Greg. (2012)."How to Make Group Discussions \& Interactions Work in the Classroom," | eHow.com, http://ehow.com/how_7879232_make-discussions-interactionswork-classroom.html

[30] Sulaiman, T., A. Hassan and H.Y. Yi, 2011. An analysis of teaching styles in primary and secondary school teachers based on the theory of multiple intelligences. J. Soc. Sci., 7: 428-435. DOI: 10.3844/jssp.2011.428.435,

URL:http://thescipub.com/abstract/10.3844/jssp.2011.428.435

[31] Swenson, Paula (2012), "Characteristics of Effective Teaching", |eHow.com, http://www.ehow.com/about_5061110_characteristicseffective-teaching.html

[32] The Compact Edition of the Oxford English Dictionary, Oxford University Press, 1971.

[33] Tuckman et al, (1979), "Judging the Effectiveness of teaching Styles: The Perceptions of Principals". The Journal of Leadership for Effective \& Equitable Organizations, SAGE Journals.

[34] Vigdor et al (2007). "Teacher Credentials and Student Achievement in High School: A Cross-subject Analysis". NBER Working Paper 13617, National Bureau of Economic Research, Inc.Wikipedia, 2012

[35] Wright, Alexandria, (2012) | eHow.com.

[36] www.cabrillo.edu

[37] www.cord.org/teaching-styles-inventory 2012

[38] www.experiment-resources.com/descritpive.

[39] www.oecd.org/edu/talis/firstresults/organization

[40] www.ryerson.ca,2012

[41] www.ssc.edu.ph 